\title{
Sustainable Community Systems: Commoning and Spatial Production
}

\author{
Zac Henson $^{*}$
}

In this article, I use a combination of Bourdieuan and Marxist social theory to analyze two community-based organizations in Birmingham, Alabama. I find that both of these organizations produce space albeit in different ways. One organization uses an apolitical form of community development that, though it produces space, partially isolates it from the community around it. While it does provide resources for the community it serves, the whiteness of the leadership and the politically averse stance of the organization prevent it from being truly effective. The second organization, while still somewhat politically averse, uses connections with local neighborhood leaders and politicians and technical assistance organizations to produce space and provide resources for the community it serves. The process of producing this space by community-based organizations is called commoning and works as a counter process to racialization and capital accumulation. [Article copies available for a fee from The Transformative Studies Institute. E-mail address: journal@transformativestudies.org Website: http://www.transformativestudies.org (C2016 by The Transformative Studies Institute. All rights reserved.]

KEYWORDS: Commoning, Space, Community-Based Organizations, Christian Community Development, Community Organizing.

Sustainability has become something of a buzzword in recent years. Originally conceived as the interrelation between the three E's, equity, environment, and economics, it has devolved into justifications for certain types of capitalist development. Arguably, it was never that radical of a concept, merely an attempt to reinvent capitalism in the face of ecological crisis, a common phenomenon in the history of capitalism.

\footnotetext{
${ }^{*}$ Zachary Henson, Ph.D., is Adjunct Professor in Sociology, Anthropology, and Social Work at Auburn University and president of the Magic City Agriculture Project. Address correspondence to: Dr. Zachary Henson, Department of Sociology, Anthropology, Auburn University, Auburn, AL 36849; e-mail: foodjusticepolitics@gmail.com.
} 